\title{
Exhibitor's Cut: Travelling Cinema and Experiences of Cinemagoing in Taurus Highland Villages during 1960-1980
}

\begin{abstract}
Based on the New Cinema History approach, this article focuses on the cinemagoing experiences in the Taurus highland villages from 1960 to 1980 in Turkey. No previous study has investigated cinemagoing experience in rural Turkey. We explore who participated in the screenings and what the experiences of audience members were, in which places (fixed or ambulant) and under what circumstances the film screenings took place, who the exhibitors were, and how procurement, distribution and exhibition mechanisms worked. We employed an ethnographic design and collected testimonies through oral history with villagers and also with travelling exhibitors and cinema operators. Our findings challenge a series of antiquated arguments on Turkish cinema history by reflecting upon grounded daily experiences in a often-ignored locality. These findings include issues such as cinema exhibition operated independently from the city, mobility and temporality of cinemagoing experience, performative audience, and open cinema spaces.
\end{abstract}

\section{Keywords}

travelling cinema; Taurus highland villages; rural cinema; New Cinema History; Çukurova region

In this article, we aim to explore how cinemagoing and screening practices constitute a social phenomenon with its spatial and temporal dimensions by comparing those practices in rural areas with the practices in the city centres. We do this through the case study of the Taurus highland villages in Turkey, in their historical context. ${ }^{1}$ By doing that we try to challenge epistemological and therefore methodological deadlock of conventional film studies in Turkey. In an attempt to close this gap, we aim to contribute to the social history of cinema and utilise a comparison of cinemagoing experiences between rural and urban settings in the Çukurova region of Turkey as well as in İstanbul. Relying on a range of ethnographic materials and oral history, we are specifically interested in the non-binary 
spatial comparison of cinemagoing and exhibiting practices of urban settings and highland villages in the Taurus Mountains as they pertain to the period between 1960 and 1980, when Turkish cinema experienced its golden age, with the introduction of new business models, increase in the number of both national and imported films and electricity arriving in most of the villages.

The New Cinema History paradigm offers far greater scope for realizing possible variations in the experience of cinemagoing in the villages, vis-à-vis the metropolitan areas or the city centres in Anatolia. Within this paradigm, over the past two decades, there has been sustained research activity on the social and cultural experience of cinema in many geographical contexts, including comparative studies. The Turkish cinemagoing experience, however, seems to be less studied, especially outside of metropolitan areas such as İstanbul, İzmir and Ankara. A small number of these studies break the tendency to look at the experiences of cinemagoing in other cities, such as Konya, Çankırı, Zonguldak, Samsun, and Van. ${ }^{2}$ However, besides these valuable studies, scholarly work on the rural cinematic experience is sparse. Therefore, we operationalise a comparative mode to 'identify and recognise patterns and conditions, ${ }^{3}$ at the same time as highlighting the spatial context of cinematic experience, in order to challenge conventional Turkish cinema historiography.

\section{Conventional cinema historiography in Turkey and attempts to write the 'other' history}

İstanbul has always been at the centre of mainstream national cinema historiography in Turkey. It is generally accepted that in Turkey, the first film recordings and screenings took place in İstanbul; national cinema has developed in the city and spread from here to Thrace and Anatolia. The companies operating in film production, distribution and exhibition, such as Kemal Film (1914), İpek Film (1928) or Ha-Ka Film (1934), were first established in İstanbul. ${ }^{4}$ The first professional organizations in the field of filmmaking and cinema - for example, the Turkey Union of Cinema and Filmmakers (1932), Indigenous Filmmakers Association (1947), Turkish Film Technicians Union (1954), Turkish Film Producers Association (1958) and Turkish Cinema Artists Association (1959) - were organised in İstanbul. The first audience organizations such as Turkish Film Friends Association (1952), Club Cinema 7 (1963) and Sinematek (1965) also emerged in this city. The perception of İstanbul lying at the very centre of mainstream cinema historiography was so dominant that it was assumed that there could be nothing more natural than the flow of a modern phenomenon, such as cinema, from İstanbul to Anatolia and the Middle East. 
This questionable phenomenon is not specific to Turkey. For instance, in the context of the United States, Allen argues a similar pattern which he refers to as 'Gothamcentrism':

Applied to film history, I would argue, Gothamcentrism refers to the related tendencies to place the metropolis at the center of historical narratives of moviegoing and to encourage the assumption that patterns of movie exhibition and moviegoing found there can be mapped to a greater or lesser degree upon smaller cities and towns in all parts of the United States at any given moment in the history of American cinema. ${ }^{5}$

Similarly, İstanbul is at the centre of the cinema history of major historians such as Rakım Çalapala, Nijat Özön, Âlim Şerif Onaran, Giovanni Scognamillo or Agâh Özgüç. Moreover, all these authors wrote the history of Turkish film industry taking İstanbul as the sole origin of the film-making. Therefore, the film-centric axis was drawn by using the product (copies of the film, scenarios); key actors in film producing (cast, producers and the crew, especially directors); marketers of the product (exhibitors and distributors, box office data etc.); product promoters (newspaper reviews, critics, etc.); and market regulators (publications, legislations and legal documents, regulations, censorship board etc.) as the major sources of this historiography, typically excluding the spectatorship. As a result, we now have a mainstream Turkish cinema history that is film-centric and mostly limited to İstanbul. Fortunately, this paradigm has begun to be contested especially starting in the early 2000s. ${ }^{6}$ However, these criticisms mostly focus on the method of historiography and they systematically ignore the fact that geographies beyond İstanbul, especially cities and suburban areas in Thrace and Anatolia, have always been a space for filmmaking and exhibition. Furthermore, in this historiography, it was hardly considered that cinema events had taken place anywhere other than metropolitan areas or city centres. Biryıldız, for example, states, through Pathé Frères in France and travelling cinema events, the screenings have not been moved out of town since the early years:

But [these] days could never be achieved, especially in Turkey; films could only be seen in movie theatres in cities ... The cinema, which started with the screenings in cafes that emerged as an urban phenomenon, had gone out of the city through Pathé, however, the development of cinema, the economic and social conditions, in particular, have imprisoned cinema in our country to cities. ${ }^{7}$ 
Conversely, various studies we conducted in Adana city centre and Taurus highland villages indicate that, since the first days of cinema activities in Turkey, travelling cinema has been practised outside of İstanbul and in a short time ambulant screenings became permanent in cities in Anatolia, but travelling cinema was also being continued intensively outside of the cities.

Despite the dominance of İstanbul and other city centres in Turkish cinema historiography, from 1927 until 1950, 75\% of the Turkish population lived in villages and towns outside the city centres. From 1950 to 1970, this rate slowly declined to 60\%, but even in 1980, 56\% of the population still lived in rural areas. Approximately 25,000,000 people lived in rural areas in 1970-1980. ${ }^{8}$ Hobsbawm emphasizes Turkey as being the 'peasant stronghold' ${ }^{9}$ in Europe and the Middle East until the 1980s. Although the rural population in Turkey is historically higher than the population living in cities and districts, the number of cinema studies relevant to cinema activities in rural areas is limited. Intellectual interest in cinema activities in rural areas especially began with the rise of the Social Realist Cinema circle and the socialist movement in general throughout the 60 s and 70 s. Social realist cinema 'echoed the hegemonic power relations of the state, filmmakers, and its audience.'10 The authors, critics and the researchers from the circle paid great attention to the cinemagoers, who had been excluded from cinema literature for years, in the context of different geographical locations. Most of these monographs and 'public interviews' published in the cinema magazines of the day.

It is these 'public interviews' published in the Seventh Art (Yedinci Sanat) magazine, which started publication in the late 1960s that inspire the research we have discussed in this article: Çeviker's cinemagoing interview with women working in brothels in Samsun and the audience interviews carried out in Çarşamba district of the same city; ${ }^{11}$ audience interviews performed by Atan and Canpolat ${ }^{12}$ in Elazığ ; Borazan’s interview with the workers in Küçükçekmece district of İstanbul about the film Friend (1974) of Yılmaz Güney. ${ }^{13}$ Specifically, author and screenwriter Osman Şahin's interview ${ }^{14}$ with travelling exhibitors who sell films in the Taurus Mountains, is an inspiration for our research. Later, during 1990s and 2000s the files published from time to time in the journal of Social History (Toplumsal Tarih) that focused on cinema life outside İstanbul are important sources: for example, studies examining İzmir ${ }^{15}$ in the early years of Republic, or studies on theatre and cinema in Trabzon ${ }^{16}$ and cinemas in the Black Sea Region ${ }^{17}$.

Among the scholarly works, the studies conducted on a cinema hall in Ankara ${ }^{18}$, Bulancak-Giresun cinemas ${ }^{19}$ and Kader Movie Theatre which used to serve from 1961 to 1977 in Oltu district of Erzurum ${ }^{20}$ are among samples of micro history studies. Scholarship focusing on the experiences of cinemagoing in 
Anatolian cities constitute the major examples of 'New Cinema History' in Turkey. For our work, we also attribute importance to the studies on old İzmir cinemas, ${ }^{21}$ especially Ylldı Cinema Hall; ${ }^{22}$ Konya cinemas between the years 1910-1950;23 Van cinemas during Yeşilçam period;24 Gaziantep cinemas between 1923 and 1980; ${ }^{25}$ Yenişehir Cinema (active in the district during Karabük industrialization period); ${ }^{26}$ studies examining Ankara cinemas and their screening experience in the $c$ ity. ${ }^{27}$ Last but not least, we draw on a project that translates as Going to Cinema as a Cultural and Social Practice: An Oral History on Audience Experiences in Turkey ${ }^{28}$ which explores, through oral history, the cinema culture of İstanbul, Ankara, Kocaeli and Antalya between 1960-1980, conducted by Akbulut and his colleagues. ${ }^{29}$

We are framing our work within the New Cinema History approach, following Biltereyst and Meers, we ask: 'What exactly and how should we compare?'30 Although any study that focuses on a particular period or location is ontologically comparative, there are not many studies in Turkey on cinema history that focus on first-hand spatial comparisons. The comparison of cinema activities in İstanbul and Anatolian cities, however, can be extremely rewarding. Moreover, many practices in rural areas differed from the practices and experiences of İstanbul and also other city centres in Anatolia. For instance, financing methods of film production were different for the İstanbul cinemas and Anatolian cinemas which utilised bond system and regional business model. Distribution policies also differed as the film's screening rights were directly transferred to the cinema enterprises in İstanbul, whereas sale of the film with the percentage model or sub-sales were common practices in Anatolian cities. In terms of the programming practices, open-air cinemas in Anatolian cities and villages were distinctive with 'two-in-one' screenings combining a melodrama and an adventure feature, and irregular screening programs. Furthermore, the city centres hosted the venues constructed as a cinema hall with regular screening programs, while 'pop up'/travelling venues of the rural areas had irregular screening programs. In the context of the audience, there was a 'disciplined'/passive viewing in the hall cinemas of the city centres, while the performative viewing was experienced in the periphery of the villages and cities. These research topics and respectively methodologies present the researchers with a large area of comparative study.

However, we cannot attribute the differences we list here as spatial boundaries specific to urban/ rural spatial distinction. After all, we can witness the performative viewing in periphery cinemas in İstanbul or a more regular programming in a village in a given year. Therefore, instead of looking at a binary context and comparing two categories, we try to look at the differentiation of cinemas in İstanbul, in Adana as an Anatolian city and in Taurus highland villages. Comparing non-binary spatial 
dimensions helps us to reveal the shortcomings of the conventional cinema history and to discuss the possibilities of comparative cinema historiography.

\section{Comparative approaches offered in New Cinema History}

Memory and archives are particularly central to New Cinema History studies. ${ }^{31}$ Rather than a film and director-oriented cinema history, New Cinema History emerged as a field of study that includes all kinds of cinemagoing, exhibition, production and consumption practices within a social and cultural context. Indisputably, the importance of written and visual archival materials in producing information about this field cannot be denied. However, the methods of oral history and ethnographic fieldwork are both epistemologically and methodologically central to New Cinema History studies, since it explores a period that is - for the most part - still in living memory. ${ }^{32}$

It should be noted that there exists research on the history of cinema among the predecessors of oral history studies. Brownlow's study ${ }^{33}$ on the American silent cinema between 1916 and 1928 is one of the first examples of oral history research. Oral history studies suggest that events that shape the lives of the vast majority are ordinary, everyday phenomena. Therefore, the facts about daily life - as opposed to unique and unusual cases - are the focus of oral historians. Thus, oral history, as Caunce states, transforms into a tool for unlacing the history to everyone, thus producing an alternative knowledge of history. ${ }^{34}$ The claim is that this knowledge is not only about what is told, but also about how history is told. For example, this is about writing the history of the ordinary, of the non-ruling in the periphery, in the countryside or various localities, as an alternative to the practice of urban, metropolitan or power-centred historiography. So the importance of direct experience and testimony in cinema historiography can be as important as where these experiences take place.

The methodology of oral history is of primary importance in the study of cinema historiography in researching the experiences directly related to the daily life practices of people in different localities. The collection entitled Explorations in New Cinema History: Approaches and Case Studies by Maltby and colleagues include various studies that utilise oral history in new cinema historiography. ${ }^{35}$ Similarly, the compilation ${ }^{36}$ titled Going to the Movies: Hollywood and the Social Experience of Cinema is also very important to understand the cinemagoing experience in various provincial geographies in the United States. Treveri Gennari and colleagues, ${ }^{37}$ who propose ontologically releasing the cinema from the city centre, and using decentralised categories in cinemagoing, should be mentioned among 
examples of local cinema historiography. Jernudd's chapter, ${ }^{38}$ concentrating on early cinemagoing in rural Sweden; Aveyard's comparative research ${ }^{39}$ in rural Australia and the United Kingdom; Bowles' discussion ${ }^{40}$ on cinema as a community-building activity in rural Australia and a chapter on cinemagoing in Flemish villages, are significant examples of decentralised cinematic experiences. ${ }^{41}$ Furthermore, numerous other publications have shaped our contextualization for comparing the urban and rural cinema practices: Marache's ${ }^{42}$ study on the cinema and social life in the rural Gironde; Zimmermann's ${ }^{43}$ study on the rural audiences to film and consumer culture in Switzerland; Biltereyst and Van de Vijer's ${ }^{44}$ study on film exhibitions in Flanders; and Thissen's ${ }^{45}$ study on rural cinemagoing experiences in the Netherlands. Mahlerwein's ${ }^{46}$ study on the Youth Centre Movement in Germany in the 1970s and 1980s (almost the same period as our study) shows commercial and noncommercial cinema comparison in rural areas; van Oort's ${ }^{47}$ study on ambulant film exhibitions in the Netherlands compares travelling cinema and fixed-location cinema exhibitions, and Srinivas's ${ }^{48}$ study provides a comparison of active-passive audiences. The studies we draft here provide the analytical framework that enables us to compare urban and rural cinemas using three contexts as the venues and exhibition, the programming and films, and the audience characteristics.

\section{Methodological Framework}

Following the works listed above, for our ethnographic research, we are inspired by a column titled "Investigation on Cinema in the Taurus Mountains" written by Osman Şahin that was published in the Yedinci Sanat (Seventh Art) magazine in 1974. The column is about travelling exhibitors who were selling films in the mountain villages. We first aimed to pursue research on cinemagoing experiences in six villages mentioned in this column (Arslanköy, Yavca, Kavaklıpınar, Tirtar, Çağlarca and Yüksekoluk) by pursuing interviews with spectators and possibly exhibitors there, but our journey was not limited to these six villages as testimonies and narratives expanded the scope of the research. We have conducted field research from July until December 2018 and compiled data through in-depth interviews in the villages of Arslanköy, Ayvagediği, Fındıkpınarı, Gözne, Kargıpınarı, Kızılbağ, Yavca, and in the city centres of Adana and Mersin to collect information on cinemagoing experiences both in the rural and urban contexts. ${ }^{49}$ Although we had interviews in seven villages, we have compiled the narration of cinema activities and cinemagoing experiences for about 40 villages in the Taurus Mountains. Throughout our research, we triangulated our data 
consisting of unstructured and/or semi-structured in-depth interviews, with other sources such as observation, local newspaper archives, local government records, and visual materials. In order to make the comparison, we use secondary sources on the cinemas of İstanbul and other city centres, which are reviewed in the first part of this article.

Çukurova, surrounded by the Taurus Mountains, is a region where human mobility has increased along with the radical transformations in the settlement processes since the $17^{\text {th }}$ century. Since then, the Yörüks, which constitute an important part of the region's population, have settled in the area between Çukurova Plateau and the Taurus Mountains, but nomadic practices have been kept alive culturally. ${ }^{50}$ Most of the villages we have visited during the fieldwork were ethnically Yörük, and some were Arab Alawites. Yörük populations are historically known as conservative, not necessarily in religious terms. ${ }^{51}$ As it is revealed in our interviews, during the period we investigate, mosques and coffee houses where men attend, constituted the public space in the villages. Men and women rarely came together in public spaces, except occasions such as film screening or theatre plays. Electricity came to the villages in the late 1960s, which mostly made a living with fruit and animal husbandry. Television broadcasts started in 1974, but no quality reception was available until satellite broadcasting began around the beginning of 1990s, because most of the villages are located in deep valleys. Except for Kargıpınarı which is situated by the Mediterranean Sea, all of the villages we visited are located at 1.000 to 1.500 meters high in the Taurus Mountains, with hard-to-reach unpaved roads. The relatively long distances and rough roads between the rural and urban areas of Mersin kept villagers away from the city during the period we investigate.

During our fieldwork, we utilised purposive and snowball sampling and conducted in-depth interviews with 7 women and 32 men. In every village, we started our investigation by visiting local coffee-houses and village governors (muhtar) first. This strategy seemed very fruitful to meet male residents since most of them who are over 40 years old were spending their time in these coffee-houses during the summertime. Unfortunately, we were able to interview fewer women for the following two reasons: first, traditionally, women settled in the village of the man they married. Therefore, many women had not experienced cinema in those villages in which we collected data (nor elsewhere for that matter). Secondly, according to our observations and also in-depth interviews, we witnessed that villages are becoming more and more conservative. Men were visible in public places, such as village coffee-houses, and we were able to meet them, 
whereas women were at their homes. In most cases, our requests to meet with women were often filtered by men, or our encounters with women were interrupted by men. Three of our participants were travelling exhibitors and two were cinema hall operators. We also wanted to explore how people of different ages and generations experienced cinemagoing. Therefore, the birth year of the participants ranged from 1933 to 1970, with an average respondent's age of 63 years. Although we aimed to document the cinemagoing and screening experiences during the period between 1960 and 1980, we were able to carry the historical narrative back to the mid-1940s in terms of understanding the social, political and economic context.

During interviews with the cinemagoers, we first asked questions to understand the demographic features of the society they lived in and the period covered in this research. After that, we asked questions try to understand their relationship with cinema/films in general, including questions such as how often they watched films, which films (genres) and/or stars liked during the period scrutinised; how they knew what film was coming to the village or to the neighbourhood cinemas in Adana city centre; how they prepared for the show; with whom they went to watch films; the state of the venue before the show (whether or not music was broadcast, what they and other audience did); experiences during the show (what they felt, and talked about while there, and so on), and the experiences of those who could not go to the cinema. In addition, we asked our participants questions about the economic, cultural, and social structure of the region/villages in which we conducted our research, from 1960 through 1980, including the political situation of the villages; their ethnic structure; whether they identify themselves as conservative or secular; whether there were activities organised by People's Houses (community centre) or People's Chambers (local branches of community centres); whether a school existed in their villages; as well as theatre activities that might have prioritized the cinemagoing experience in the villages. We also tried to understand whether cinema activities had a role in various social relations.

Regarding interviews with the cinema operators and travelling exhibitors such as Ömer Dündar, Nazım Dündar, Sami Dündar, Sinan Öz and Hasan Kınalı, we focused on the economics of cinema activity, attempting to understand why they decided to get into the 'cinema business'; how they raised their capital and learned to operate; the costs of film supplying and other costs; the ticket sales price; the taxes and/or fees they paid and their relations with the local administrators. To be able to 
collect information on the screening programs, we investigated which films they decided to screen and how they supplied those; how they promoted the screening program; information about the screening schedule of a film (including the number of sessions, number of days); and the characteristics of summer and winter screening seasons. Through our questions, we tried to reveal the daily and seasonal routines of screening. We also asked them about the equipment they used for film screening; audience capacities; characteristics of the venue in which the films were screened; formats they screen $(16 \mathrm{~mm}$ and/or $35 \mathrm{~mm})$. Also, cinema operators and travelling exhibitors were asked about the experiences of the audience before, during and after the screenings. Who participated in the screenings, whether the elderly, youth, children, women or men? Were there screenings for women or children exclusively? How was the seating arrangement? Was there a hierarchy between women and men, young and elderly? And, what was their route? The map below (Figure 1) depicts two main routes that travelling exhibitors have followed. These routes are the ones we traced for cinemas as well.

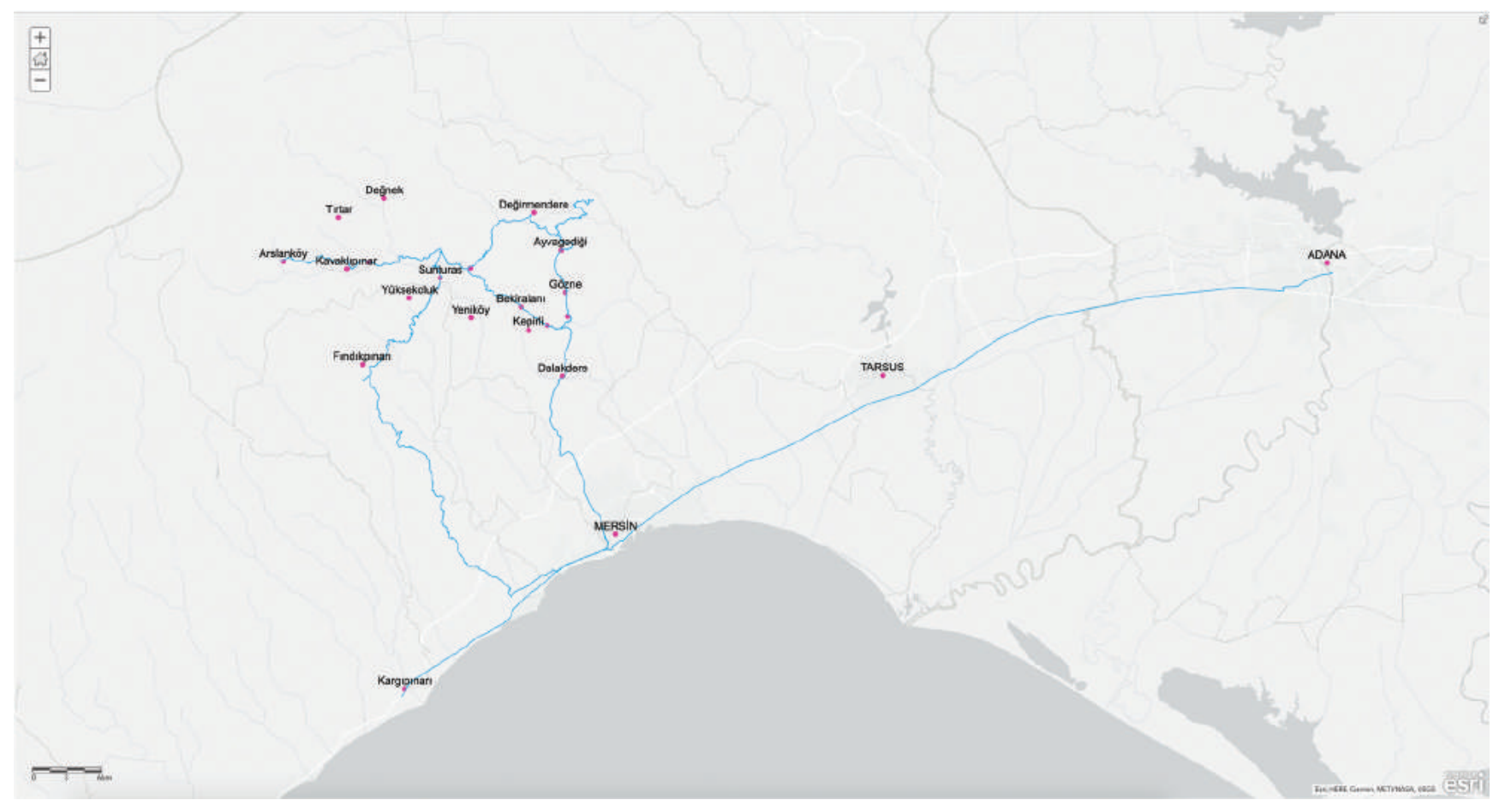




\section{A comparative exploration of cinemagoers in rural Turkey}

\section{History of film exhibition in the region up until 1960}

The screenings in the Taurus highland villages started as a public activity to generate information on 'modern life' to spread the secular-nationalist values and modernist ideals of the newly established Turkish nation-state. For instance, following the opening of Adana, Tarsus and Mersin People's Houses in 1933, films on civil defence, public health and hygiene, modern agricultural techniques or propaganda films of the newly formed republic were screened in the villages. ${ }^{52}$ The People's Houses are cultural/community centres that were established in the cities by the government to gain popular support and served as the semi-official organ of the governing party. As outlined by Adadağ, ${ }^{53}$ about 500 People's Houses were operating across Turkey by the time they are closed in 1951. In addition to organizing various educational and cultural activities, such as increasing literacy, exhibiting theatre plays, organizing sports competitions, teaching playing musical instruments, these institutions became major venues for cinematic activities by "purchasing cameras and projectors, procuring films from various sources to show to the public, and shooting films of its own [and providing] a public venue for screening these films. ${ }^{54}$ These institutions and their cinema activities were similar to the People's Houses in small towns in rural Sweden, which served mostly after WWII a non-commercial cinema sector ${ }^{55}$, though as grassroots initiatives of workers' societies rather than state-owned institutions.

During the beginning of the 1940s, the film screenings became widespread with the opening of the People's Chambers - a smaller version of People's Houses with fewer resources - in the villages and smaller towns, and many people encountered cinema here for the first time. Before the arrival of cinema, performing theatre plays within branches of People's Houses and People's Chambers, prepared the audience for the show. ${ }^{56}$ In addition, - in parallel with the ideals of modernity of the new Republic - playing popular music and sometimes folk music before the film screenings in the villages constituted the screening order. According to local residents, the first screenings in the villages of Taurus Mountains were held in the last years of WWII. Soon after, it became widespread as a commercial activity in the form of travelling exhibitions and fixed-location halls as well. In the second half of the 1940s, film screenings were made through travelling exhibitions, even at the most distant mountain villages of Adana and Mersin. In 1947, the first film was screened in Arslanköy, 70 kilometres from Mersin and at an altitude of 1,500 meters, with the technical support of the US military personnel in the Çukurova region. ${ }^{57}$ This first film roll was a set of fragments from Tarzan, 
the movie, ${ }^{58}$ a short clip from Mickey Mouse, an excerpt from a Laurel and Hardy film, and a documentary on 'the US-Japan War’ as writer Osman Şahin, a resident of Arslanköy, recalls:

I can say that the first time we saw the ships, the guns, the cannons, the tanks, the horrors of war in that movie. This must have been the actual war that our grandparents who have experienced mobilization told us. Then, when a fighter jet that fires in the movie falls into the middle of the white screen and explodes, I can’t forget that the villagers standing near the curtain escaped. ${ }^{59}$

After the war movie, another documentary on how American farmers grow corn was screened. Turkish villagers were able to observe American farmers while eating their meals, taking showers and resting. According to Şahin, the whole spectacle, even the arrival of US marshals with a motorized vehicle, was fascinating and embraced by the villagers. Only a year later in 1948, after the first US-backed screening, travelling exhibitors - who arrived with the projectors and electric generators they carried on the back of a mule - screened films in Arslanköy. These exhibitors were commercial entrepreneurs. ${ }^{60}$

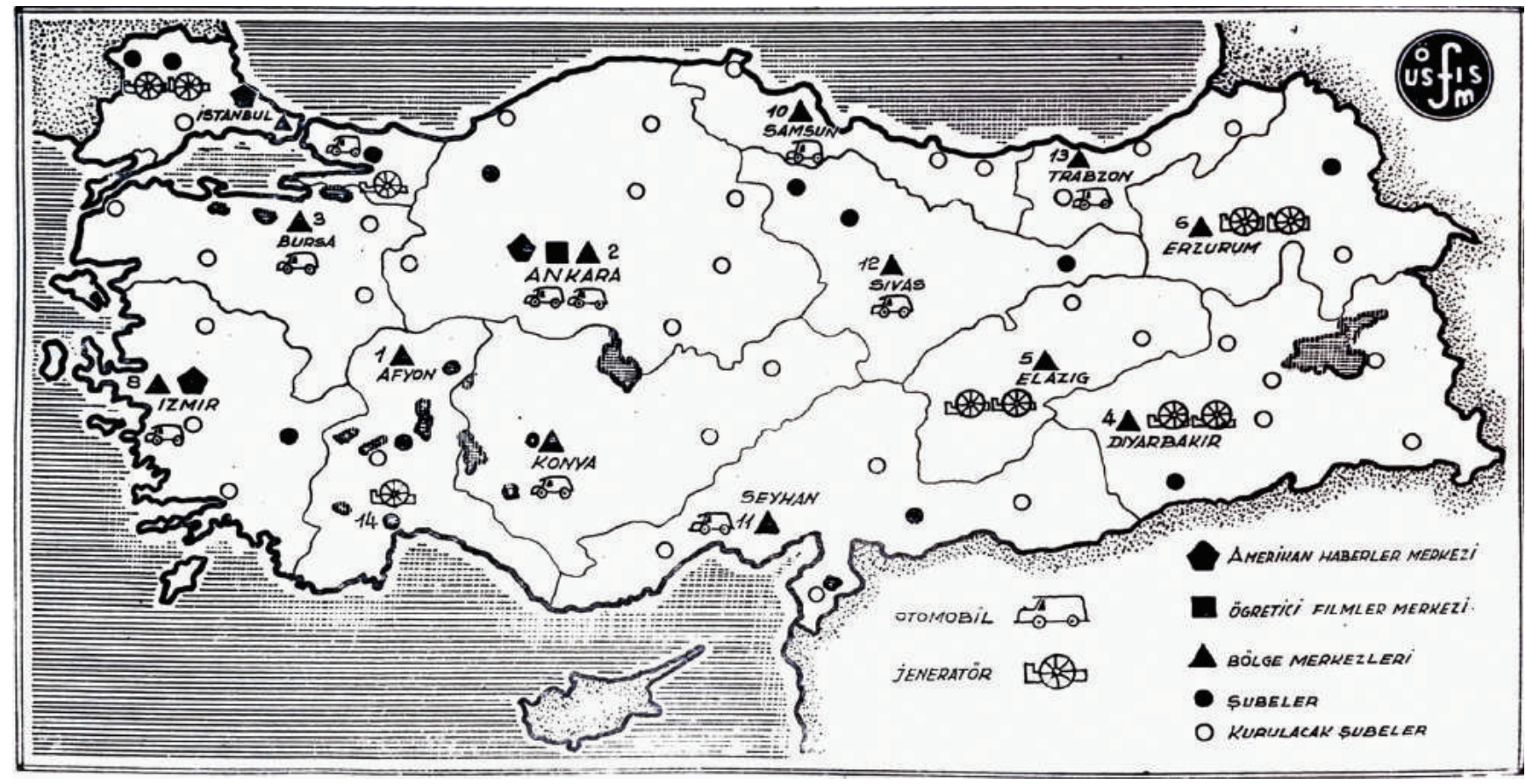

Figure 2. A map showing the operations run by United States Information Service in cooperation with Educational Films Centre, 1952.61 The legend translates as follows: $\Delta$ USIS, Educational Films Centre, $\mathbf{\Delta}$ Regional Centres, - Branches, $\bigcirc$ Branches to be established 
However, the US involvement was not only limited to the first exhibition. Educational Films Centre was established under the Ministry of Education in 1951 and centre's film screening activities all over Turkey has continued in cooperation with United States Information Service (USIS), an agency to promote the US interests through foreign public diplomacy. USIS has provided films and infrastructural support to the Centre. ${ }^{62}$ According to the film catalogue has published in 1952, ten cinema vehicles were used 'in order to reach the villages that do not have electricity and accompanied with a teacher assigned by the Ministry of Education'. ${ }^{63}$ Seyhan zone has served to Adana and Mersin region.

\section{The infrastructure, the venues and exhibition}

A highly dynamic cinema activity took place in the Taurus highland villages, especially between 1960 and 1980. Our interviews reveal that, since the 1960s, Musa Özder and his brother Mehmet, who previously dealt with travelling cinema, organised regular film screenings in Arslanköy both in the open air and in a hall provided by the People’s House. In 1972, Sami Dündar and his sons Nazım and Ömer opened 300-seated Cinema Art, the second cinema hall of the village. During this period, there were halls, open-air, terrace/rooftop, garden and plateau cinemas in the villages of Arslanköy, Güzelyayla (Kızılbağ), Gözne, Ayvagediği, Kargıpınarı and Fındıkpınarı where regular film screenings took place. In addition, film screenings were being performed by travelling exhibitors in almost every highland village, particularly in the villages of Tırtar, Yavca, Değnek, Değirmendere and Dalakderesi.

It should be noted that the spatiality of the screening places that we identified during our research in the Taurus highland villages differed significantly from the cinemas in metropolitans or city centres. Harvey, on the spatialities of cinema, states: 'The combination of film and music provides a powerful antidote to the spatial passivity of art and architecture. Yet the very confinement of the film to a depthless screen and a theatre is a reminder that it, too, is space-bound in some curious way. ${ }^{64}$ This proposition contains all the stereotypical expressions of the conventional approach we have challenged during our study. During our research, we witnessed a wide variety of cinema places in the villages of Arslanköy and Kargıpınarı. For instance, in Arslanköy, film screenings were performed in two halls, Cinema Arl and People's House Cinema, while open-air film screenings were held in the gardens of the Çınaraltı Coffee House or village school. After the closure of public institutions of People's Houses in 1951, in Arslanköy, the venue served as a semi-public space hosting village governorship, a library and a theatre, later making a perfect hall for in-house film screenings 


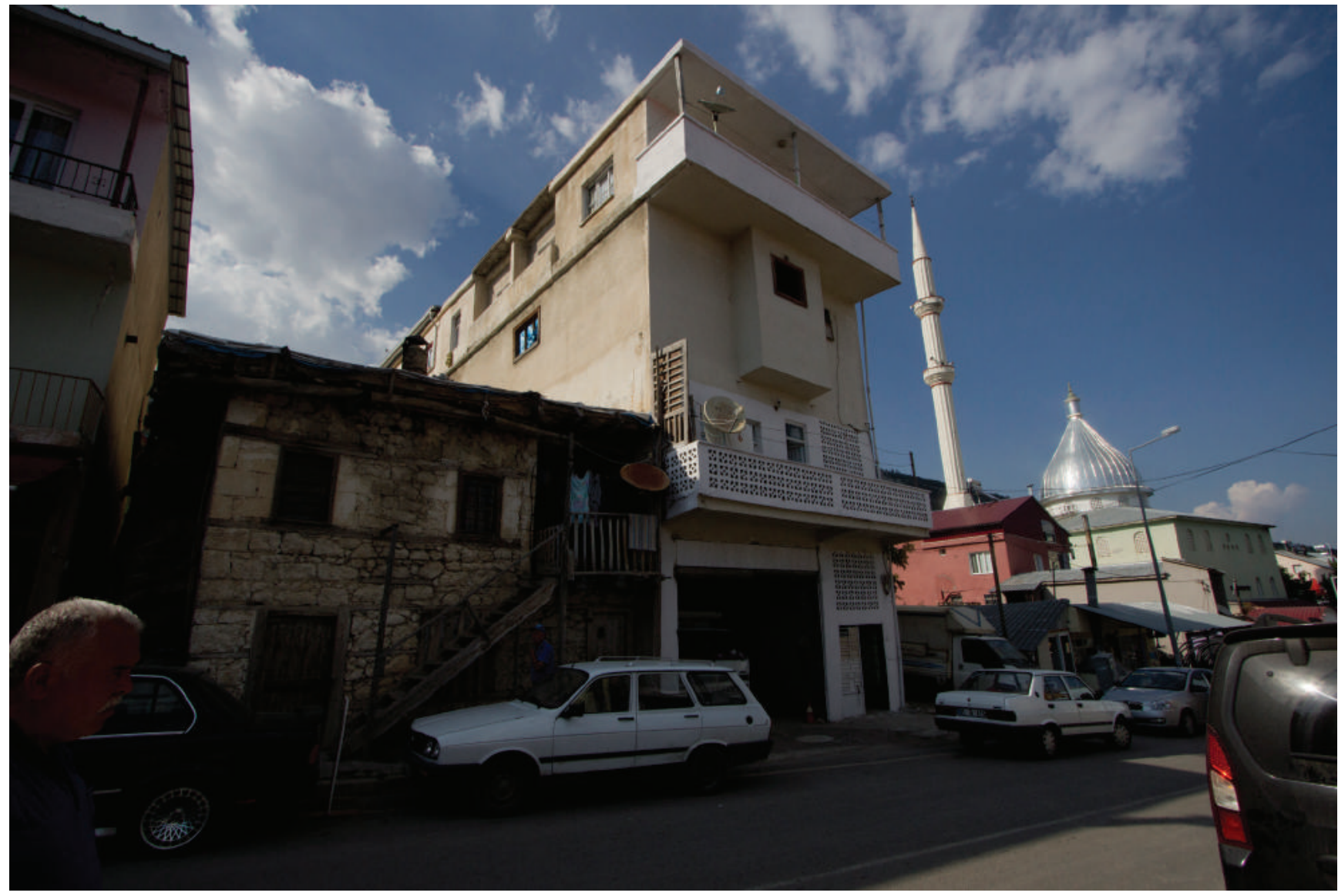

Figure 3. Cinema Arl, a lounge cinema in a small Taurus Highland village (Arslanköy, Summer 2018)

by a commercial entrepreneur Musa Özder. Above the 800-seat hall of the Municipality Cinema in Kargıpınarı, there was a terrace/rooftop cinema with film screenings during the summer season. We encountered a similar terrace cinema in the village of Güzelyayla (Kızılbağ), which was almost leaning on the foothills of the Taurus Mountains, which loomed high behind the projection booth.

We found that film screenings were being held in all kinds of spaces suitable (and sometimes not very suitable), in coffee houses, school gardens, village squares, in dozens of villages such as Yavca, Tırtar, Değnek, Değirmendere, Dalakderesi, Yeniköy and Aladağ. As in the villages of Gözne and Ayvagediği, temporary highland cinemas that were operated for only three months during summer are mentioned in first-hand encounters. One example was named as Cinema Dilek, which was operated by travelling exhibitor Hasan Kınalı. ${ }^{65}$ 


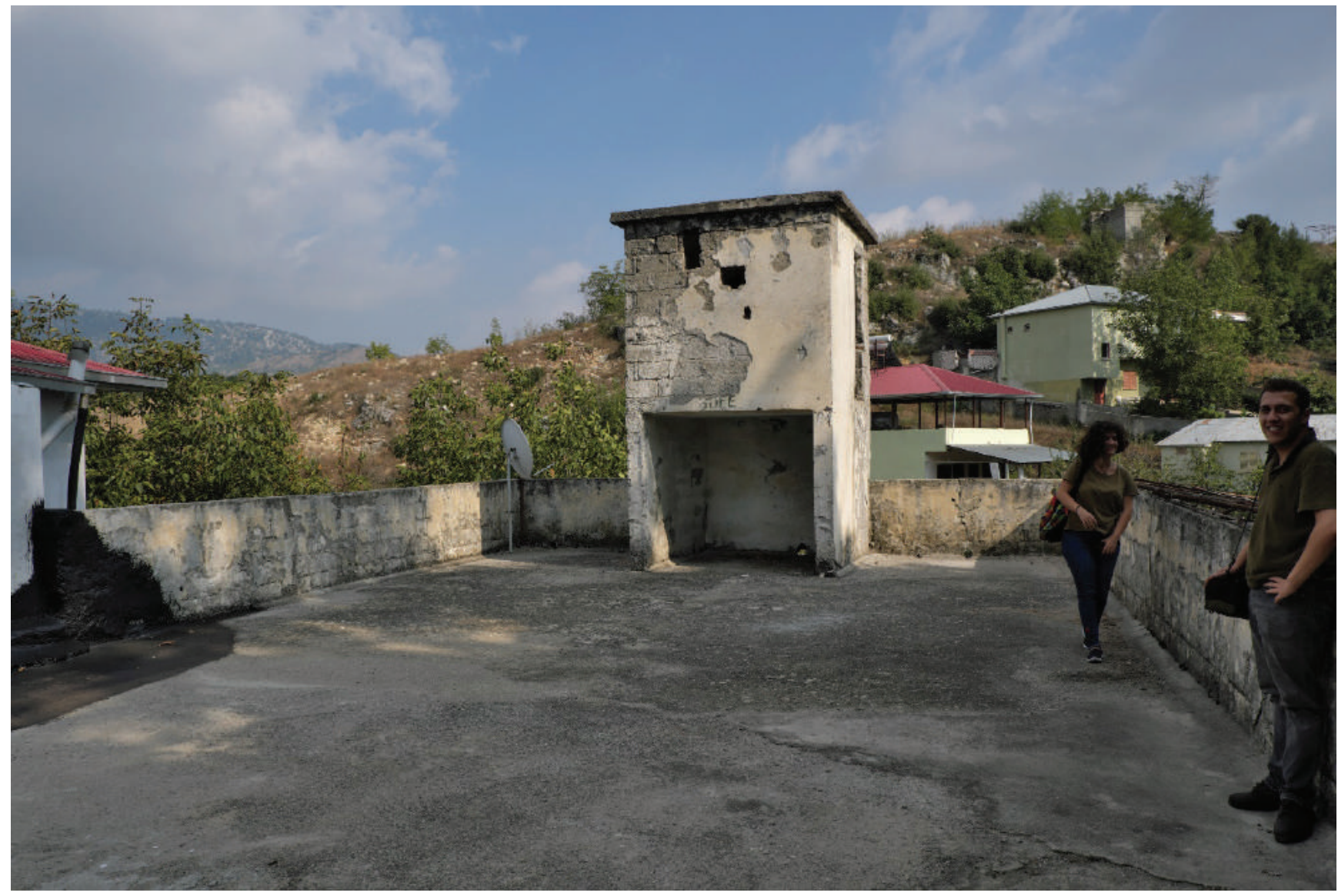

Figure 4. The projection booth of an open-air cinema in the view of Taurus Mountains (Kızılbağ Village - Taurus Mountains, Summer 2018).

During summertime, I was screening films open-air. It was a half-fixed-location space. Just an empty land with a white wall as a screen. I named it Cinema Dilek and even made a banner with the name on it. I built a wooden projection booth to use all summer. When the winter came, I was going to schools [to show films]. I was screening films on Atatürk or historical films.

We learned that both terrace/rooftop cinemas were being operated in Findikpınarı located at the base of a valley surrounded by the Taurus Mountains, and because of the lack of signal for television broadcasts, there had been intense cinema activities until the mid-1990s. Abdullah Demirtaş, whom we interviewed within the framework of the research, conveys poetically that 'the screenings were performed under the poplar trees in the open-air cinema in Findıkpınarı', where he spent his 


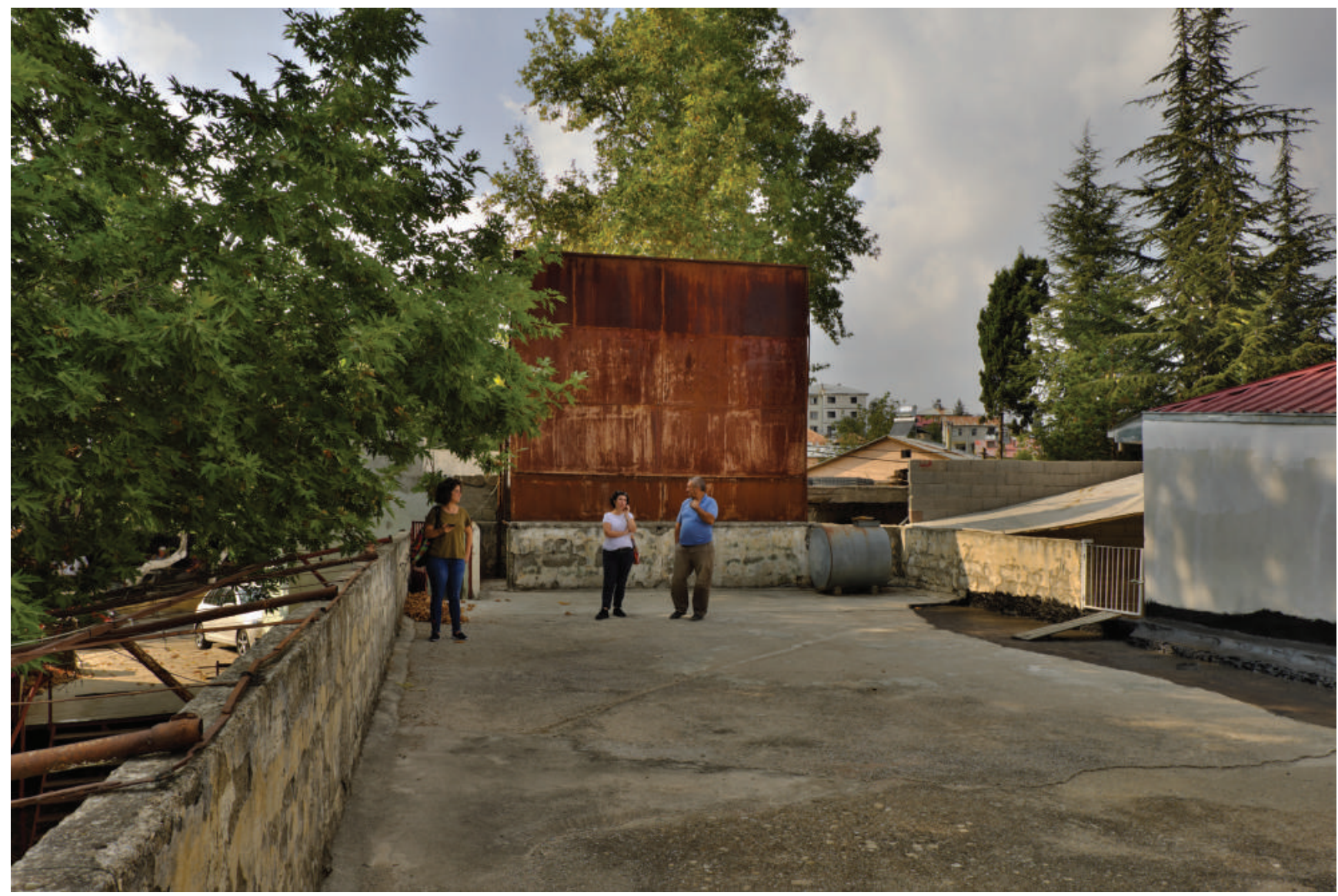

Figure 5. The ironwork screen of an open-air (terrace) cinema's screen (Kızılbağ Village - Taurus Mountains, Summer 2018).

childhood and youth, and sometimes he was captivated by projector beams leaking between the leaves of the trees. ${ }^{66}$ Both the screening venues that we have found during our field research and the experiences expressed in in-depth interviews show that there were very different screening spaces from the traditional/conventional cinema venues. Such physical structures of these spaces combine the cinema experience with the physical world, as opposed to the closed and dark halls that make the cinema experience isolated from the physical world as much as possible: projector beams leaking through the branches of trees, a primitive curtain stretched to the mud-brick wall of a school or a coffee shop; projectors installed on a table or rack; flimsy projection booths; seating arrangement set up with chairs borrowed from the coffee shop or desks taken from the schools; those who often sit on rugs. One of our participants even added that 'Those who could not find a chair would bring a mat or a 
rug from their own homes ${ }^{\prime 67}$ to be able to attend screenings in those make-shift cinemas. Films were watched while sitting, lying down, standing or even on horseback.

These venues had different characteristics between the city centres and the villages. In this period, we can classify the films and screenings shown in Çukurova Region, especially in Adana city in three main groups. The first group includes transnational and national major productions and the places where they are screened. These are usually venues designed in a 'modern' style equipped with comfortable padded seating, better technology and quality programming. People socialise not in the auditorium, but rather in the foyer area. In the second group, screening venues presented national productions of historical adventures and melodramas. These spaces are hall cinemas in the suburban areas of the city, mostly named as 'neighbourhood cinemas' and open-air cinemas that have been

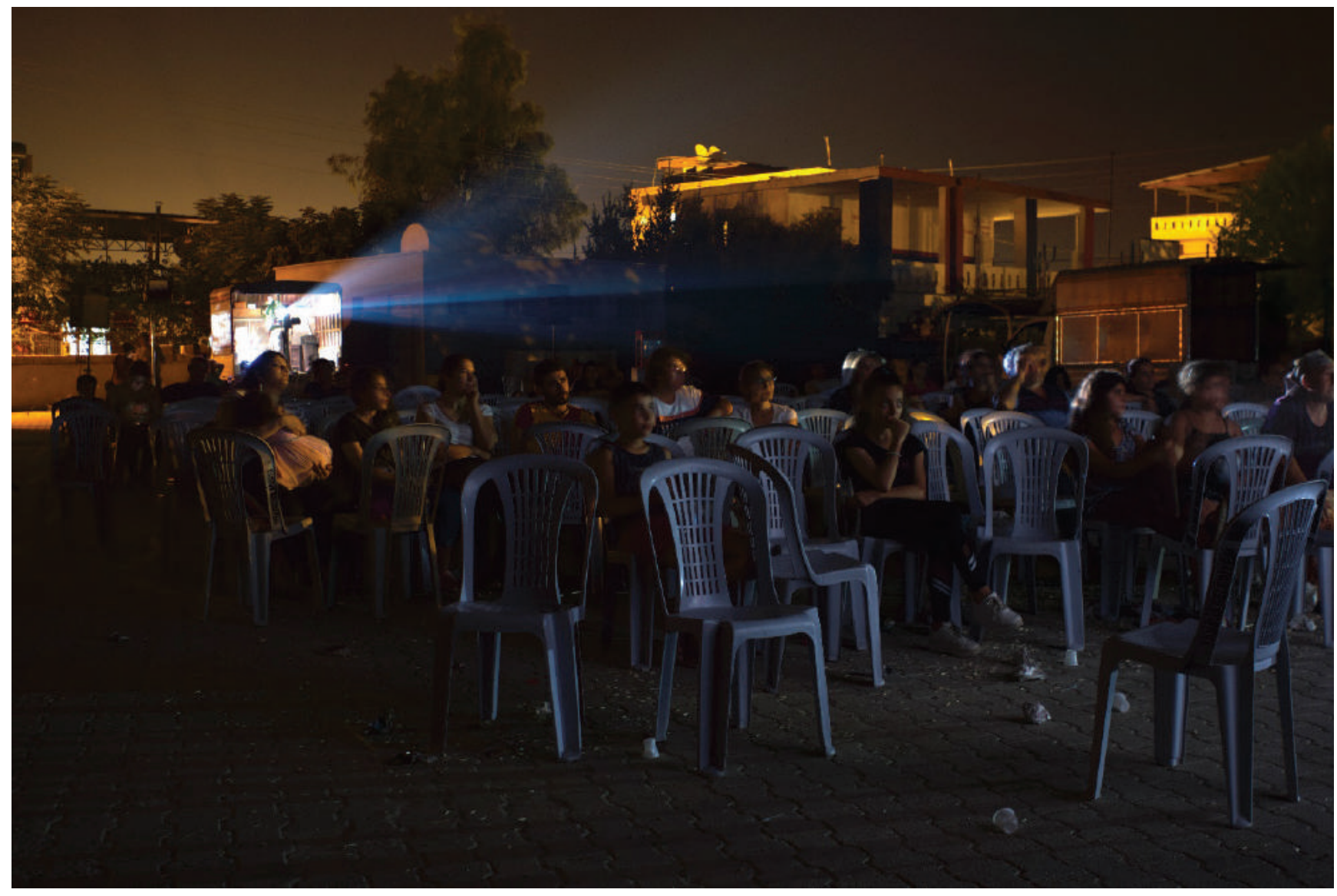

Figure 6. Re-enactment of a travelling cinema exhibition in a school garden - Cinema Nostalgia (Ali Efendioğlu Village - Tarsus Plateau, Summer 2019). 


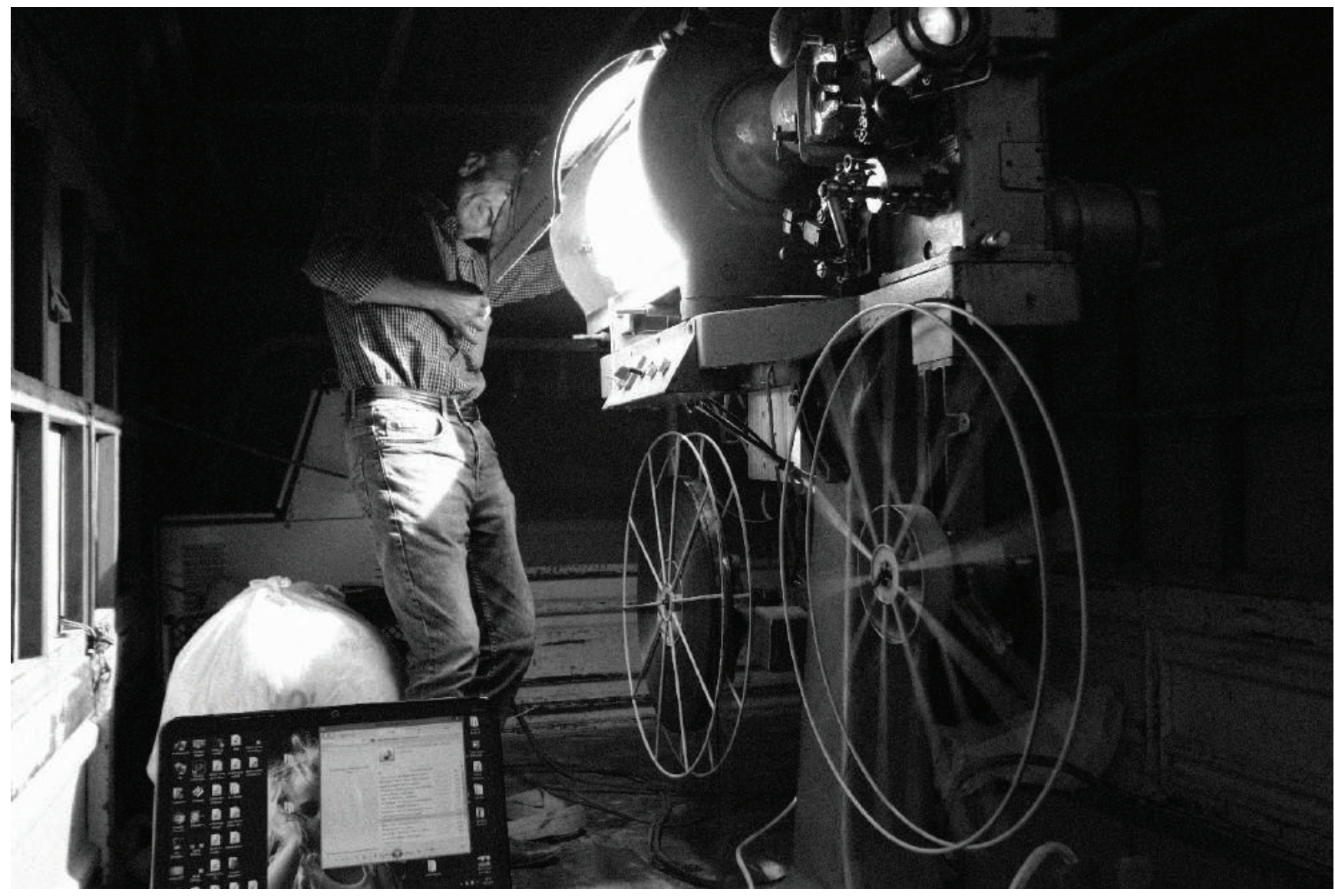

Figure 7. A travelling cinema projectionist controls the light intensity of a 35mm film projector, which is mounted on a truck bed, during the re-enactment of summer time open-air cinema

(Böğrüeğri Village - the Taurus Mountains, Summer 2019)

spread all around the city. The third group consists of the villages where the travelling cinema activity lies in the centre and the films are shown in the villages. The cinema venues in the villages are very diverse ranging from makeshift cinemas on a school's wall to an 800-person permanent hall, or to open-air spaces. The films shown in these venues have very strong local characteristics. In most cases, films are screened at open-air venues under the trees and stars during summertime. Soon after getting $16 \mathrm{~mm}$ reels from Adana, the travelling exhibitor arrives in the village afternoon, settles at the local coffee-house, and announces which film will be shown that day. He stretches the screen sometimes between two trees, or sometimes on a wall and makes seating arrangements by using the wooden chairs of the coffee-house. This practice, seen early in the history of cinema in Europe, for 
example in the Netherlands ${ }^{68}$, continued in the Taurus highland villages in the 1960 s and even in the 1970s. Although there were open-air cinemas in the city centres as well, those in the villages were not fixed, but rather flexible in terms of spatial organization.

\section{Programming, the cycle of screening and films}

First of all, the films shown in towns and villages were different from those shown in the cities. Except for the silent films screened by travelling exhibitors in the early 1940s period, only Turkish films were shown in this region. Moreover, these films were highly localised. The local/regional business model is the basic production model of the golden years of Turkish cinema which was initiated after the 1960 military coup and ended after TV broadcasting spread nation-wide in 1975. According to this model, the country was divided into six geographic districts (centred in the cities of Adana, Ankara, İstanbul, Izmir, Samsun and Zonguldak) and the producers, in İstanbul and elsewhere, were organised around two common models of production and distribution: (1) the film is distributed to commercial cinema operators in exchange for a certain commission of the revenue, which was calculated after the removal of the local taxes and sometimes the advertising costs; (2) the transfer of the film's right to show for a fixed price. In both models, İstanbul-based companies depended on local producers and operators; and after a while, the demand from local partners began to determine the form and the content of the films produced. ${ }^{69}$ During our fieldwork, we observed that films referring to local myths and narratives were distinctly remembered. Thus, the narratives and narrative structures of these films are local. Furthermore, the production, distribution, and demonstration of these films are also local and distinctive, characterizing the epoch. Consistent with a local/regional business model, these films met the local demand by featuring local elements belonging to Yörük culture. The films that our participants remembered most of all are Kara Sevda (Blind Love-Seyfi Havaeri, 1968), Ala Geyik (Fallow Deer-Süreyya Duru, 1969), Boş Beşik (Empty Cradle-Orhan Elmas, 1969), Karagün (Dark Day-Bilge Olgaç, 1971), Kara Duvak (Black Bridal Veil-Mehmet Bozkuş, 1972), Kızgın Toprak (Hot Soil-Feyzi Tuna, 1973), Mağrur ve Cesur (Proud and Bold-Çetin İnanç, 1973), Kara Çadırın Kızı Zeynep (Zeynep, the Girl of the Black Tent-Orhan Elmas, 1979) and Gülüşan (Bilge Olgaç, 1985). All of these recalled films reveal cinematographic and narrative patterns in the manifestation of local stories, of Yörük culture and traditions, of music, of places where the films were shot, and distribution that are outlined in Table 1. 


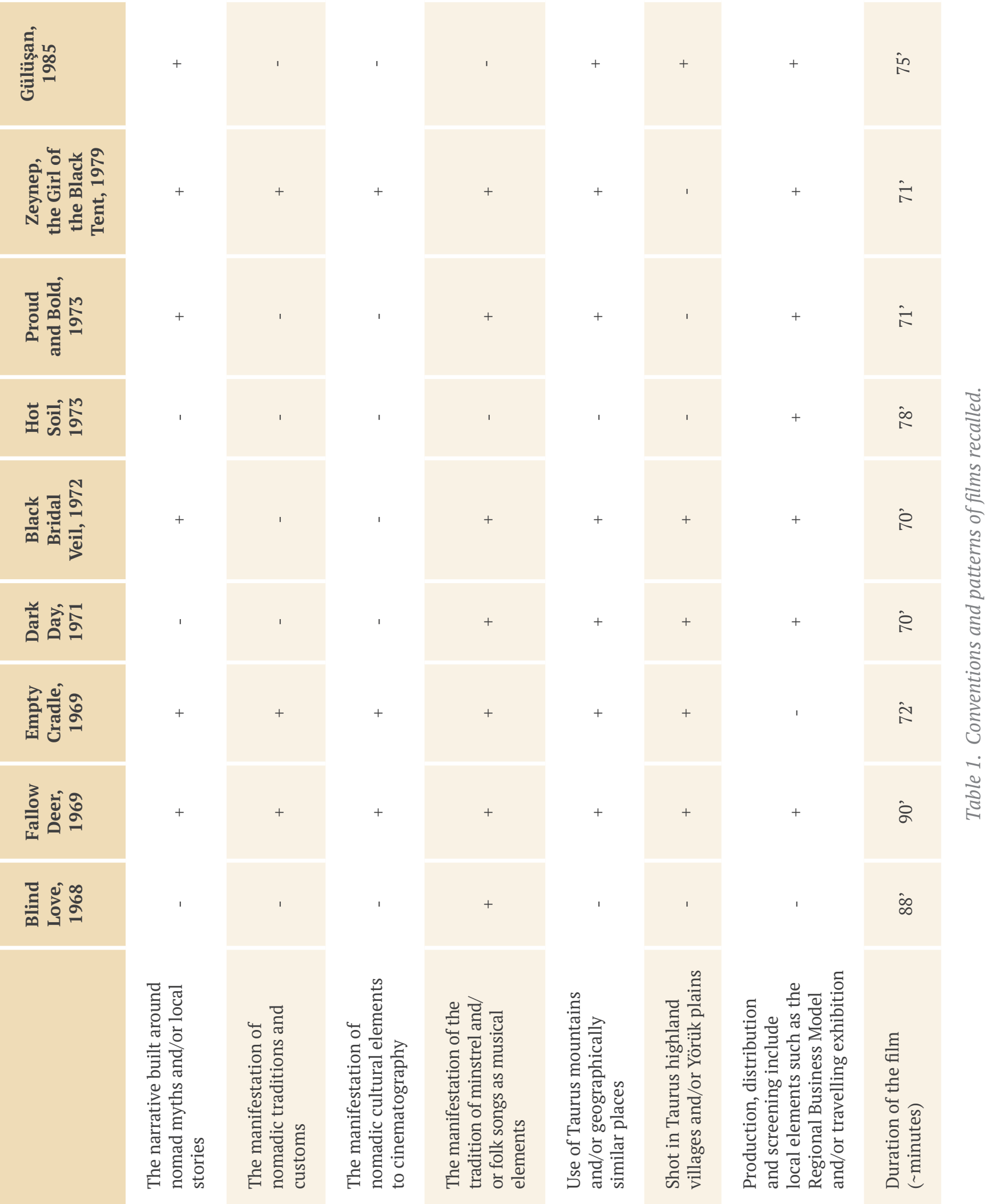


Travelling exhibitors screened films in the villages according to their ethnic and religious structure. For example, in addition to 'village films', Musa Özder ${ }^{70}$ talks about screening films with Islamic themes, the ones that revolve around religious/Islamic personalities to be able to be welcomed in some villages, specifically in more religious ones:

For example, there was a Qur'an teaching school in Kızılbağ village where I first went. The Imam was opposed [to a screening]. 'Cinema is demon work, it is immoral,' he said... I knew this would happen, so I screened Mevlut'un Doğuşu [Birth of the Prophet] first. I even served sugar and cologne to the audience. I did not get the money. The Imam liked what I did. He made all the villagers come to the film. The village square overflowed. When the prayer was called in the film, the audience stood up. The old people were praying and crying. You have to screen religious films. Later, when the audience got used to the cinema, I screened village-themed films. ${ }^{71}$

Özder was given carte blanche to continue to screen films for years.

Another disparity between the rural and urban areas is the screening policies. Both in the city centre and the villages, there are differences between the luxury movie theatres and other cinema venues. For example, luxury movie theatres almost always include first-run films in their programs, whereas in the neighbourhoods and open-air cinemas at the periphery, double-bill programs include one first run and one-second run film. In the case of villages, the situation is completely different and the films shown do not matter in this respect. In the words of the travelling exhibitor Hasan Kınal1 ${ }^{72}$, 'every film shown is already the first screening for the villagers'.

\section{Characteristics of the cinemagoers}

As our participants mentioned, almost all village inhabitants attended screenings, and therefore going to the cinema and watching films in villages and towns was a popular activity. However, despite the efforts of People's Houses 'to discipline the audience ${ }^{73}$ and unify them everywhere, the experience of cinemagoing in the villages was quite different from the metropolitan areas, specifically from İstanbul.

In addition, functional components are also different. In 'disciplined' luxury movie theatres, buffets and toilets are typically located in the foyer area, i.e. outside the screening area, while buffets and toilets in the neighbourhood and open-air cinemas are located just below the screen. For example, 
Cinema Arl in Arslanköy has such characteristics, although it is a hall. At the Cinema Arl, buffets and toilets are located inside the screening space, under the screen. In most cases, city or metropolitan cinemas do not differ from the others, only in terms of the films or the design of the space, but they demand differences from the audience as well. For example, the audience attending the screenings in these cinemas are expected to be 'modern' and 'disciplined': the audience is not allowed to come to these cinemas with local/traditional clothing, for example, shalwar. After the screening starts, the audience is not allowed to enter the theatre and leave before the break; it is accepted as crass behaviour to speak, to make noise or to eat something during the screening and the theatre is non-smoking.

Cinemagoing and exhibiting experiences we have listened to at Taurus highland villages are reminiscent of the studies conducted by Srinivas in India. ${ }^{74}$ Srinivas states that spectatorship in India is quite different from a more disciplined experience. For instance, in India, cinemagoing takes place not as an individual but as a kind of communal experience. Sometimes a group composed of peers or sometimes families with members of all ages go to the cinema. Watching the film is accompanied by intense noise in the form of jokes, shouting, laughter and sometimes crying. Based on this comparison, experiences in the Taurus highland villages are very similar to that in India. It also conforms to a 'rural' experience: the notion of cinemagoing as an extremely individualised and highly disciplined action is also contested in some European cases. There is also a marked difference between urban, first-run cinema experience and more rural or neighbourhood cinemagoing experience.

Spectators go to the cinema to Arslanköy in groups from closeby plains. Moreover, both residents of villages such as Arslanköy or Yavca and potential participants of the screenings in these villages, who live in the nearby plains, are mostly members of the same family. Almost all of the people who fill the hall or the area where the screening takes place know each other. Therefore, going to the cinema is considered as a gathering; they gather to go to the cinema, gather for screening, and 'gather to re-narrate the film on the days after the screening event'. ${ }^{75}$ Depending on all these gatherings, the experience of spectatorship starts well before the show and ends long after it. The coming of travelling cinema is announced much earlier and those working in the fields or gardens excitedly prepare to watch the films. Furthermore, hours before the screening, the travelling exhibitor begins playing songs from the record player or tape-recorder to call the crowd to the day's event. ${ }^{76}$ Thus, cinemagoing experience includes an exciting preparation period and this excitement continues during the screening. 
As outlined earlier, according to the conventional Turkish cinema history paradigm, the audience is asked to watch the film in awe with absolute silence and almost captivated. The audience is expected to be a silent witness during the screening and an invisible witness before the film, as Elsaesser and Hagener write:

In the classical cinema the spectator is an invisible witness - invisible to the unfolding narrative that does not acknowledge his/her presence, which is why neither direct address nor the look into the camera are part of the classical idiom... The spectator figures either as an invisible witness, or is invited as a virtual participant of events taking place independently of him/her, yet happening in a shared world (outside the cinema). ${ }^{77}$

However, being invisible during the screening, in other words, the passive position of the audience in front of the film, was not observed in the Taurus highland villages. The screenings are also 'very exciting and enthusiastic'; ${ }^{78}$ 'the audience gets up and sits from the excitement'. ${ }^{79}$ For example, 'when the call to prayer is recited in a scene in the film, everyone stands up due to respect'. ${ }^{80}$ The sounds of those who cry combine with the jokes and waves of laughter made about the strange situations of those who encounter cinema for the first time; sometimes those who watch a film for the second time begin to cry even before they see the scene again. ${ }^{81}$ Crying continues even after the film ends. According to travelling exhibitor Hasan Kınalı, he also joins those crying women in the cinema: 'Women cried and I cried. Even after the lights were on, there were always crying (...) you'd be surprised to see those peasant women'. ${ }^{82}$ Audience accompany the fights on the screen by shouting: 'Shoot, shoot!' When the protagonist of the film wins a fight, the cheers raise, the audience whistle or stone and even shoot the villians on the screen. ${ }^{83}$ When the heroes portrayed by popular actors such as Cüneyt Arkın or Serdar Gökhan take the flag in a film and raise it above the castle, everyone gets up and applauds. ${ }^{84}$ Or in a romantic scene, when male and female characters get close, for example when they kiss, objections arise from older women. ${ }^{85}$

Moreover, the performative watching continues even after the film ends: Immediately after the screening, the scenes in the film are re-played by the audience, especially by the children. The audience narrates the film to those who do not watch; films become the main subject of daily conversations until the next screening. The cinemagoing experience, which begins hours before the screening, sometimes continues for days after it. In this process, the audience is never passive in front of the screen; on the contrary, highly active and performative. In this respect, it has almost no 
resemblance to the 'modern' notion of audience and the cinemagoing experience, and it has the characteristics that Srinivas states regarding spectatorship in India. 86

\section{Rural cinemagoing as a sign of cultural accomplishment}

The history of modernity, city, and cinema has been written together and these three are often thought of being in a symbiotic relationship. However, the relationship between cinema and modernity has been strongly established even without the intermediary of the city. First of all, it is suggested that cinema is directly the art of modernity and that no art can represent modernity better than it. According to Mario Pezzella, cinema is the art of modernity (un'arte della modernità). ${ }^{87}$ For Jean-Paul Sartre, cinema is the most obvious means of representation of time:

It is an art which seems easy but is really extremely hard and, if it is approached in the right way, very profitable; because by its nature it reflects civilization in our time. Who will teach you about the beauty of the world you live in, the poetry of speed, machines, and the inhuman and splendid inevitability of industry? Who, if not your art, the motion picture. ${ }^{88}$

Hobsbawm states, 'Yet no art represents the requirements, the unintended triumph, of an utterly untraditional artistic modernism more dramatically than the cinema' ${ }^{89}$ Orr, furthering the relationship between cinema and modernity, argues that cinema, 'as an innovative form [...] challenges both the conventions of the modern artwork and modernity itself'. ${ }^{90}$ As the literature cited above, going to the cinema is the most important activity of modern city life and thus, in a way, going to the cinema is a necessity of modernity. So, it follows that going to the cinema, which is modern art, is a necessity of being urban and a marker of being civilised.

It is noteworthy that during the study we conducted in the Taurus highland villages, the participants often used some of the references attributed to cities, especially metropolitan areas, for their villages. ${ }^{91}$ Biltereyst and colleagues' collection ${ }^{92}$ offers similar arguments of historicizing film exhibition, cinemagoing and spectatorship within the context of modernity. In one of our interviews, for instance, Bilal $\mathrm{Ay}^{93}$ states that the inhabitants of Arslanköy are not only from one ethnic group, but also from many different parts of Anatolia, especially in Çukurova Region, and in this respect, the village is highly 'cosmopolitan'. For this reason, it is perhaps not a coincidence that the village hosts fixed-location and travelling cinemas or uses its cinema halls for concerts, theatre plays or other cultural activities. Sami Dündar, who takes his name after his grandfather, the founder of Cinema Arl, 
who still lives in Mersin but spent most of his childhood in Arslanköy, makes the same emphasis, and states that Arslanköy stands out with its educated residents, culture, cinema and theatre and adds that the village is 'cosmopolitan'. ${ }^{94}$ Within this context, it is also important that Sami Dündar defines staying away from cinema as 'cultural deprivation and recession'. Going to the cinema means being educated, independent of literacy, and being civilised. Between 1960 and 1980, when fixed-location and/or travelling mobile cinemas worked effectively, in a period when the interactions between the city and the village were hardly established, women watching films together with men is considered as a modern cultural activity:

Everyone came to the cinema with women and men at that time. No one found this odd. It was considered as a different culture. Just like today, everyone can go to the cinema. There is nothing wrong with that. At that time, we are talking about the 70 s and a closed society, especially in Arslanköy, this was not considered odd in any way. ${ }^{95}$

Although women were attending the screenings, which become a public space where everybody can mingle, in more conservative villages, there was visible gender segregation:

Of course, women came to the screenings as well. But they would sit behind the men.

Older men were sitting in front and then younger men. Women were behind those men and children, especially those who don't have money to pay for the ticket would stay at the back of the audience... We were lining up the chair in rows. The seniors, the notables of the village sitting at the forefront. The youngest ones are at the back. For example, sometimes most wouldn't have money. I would say to them, 'You sit there and watch', just about 9-10 years old. He wants to watch. There was so much poverty by then. No-one had a motorcycle or a car, even electricity had just arrived. There were a lot of people who had never been to the city. ${ }^{96}$

Almost all of the participants that we interviewed during our research, with nostalgia, identify both the art of cinema and the cinemagoing activities as being civilised and/or being accultured. This corresponds to the aforementioned assumptions: going to the cinema is associated with being cultured in the city or village; conservatively rejecting cinema is considered as not developed or uncivilised. Furthermore, we can say that those who live in these villages have equally as great cinemagoing experiences as many of the residents of cities. In the summer season, which starts in April - May and ends in September - October in Taurus highland villages, travelling exhibitors and 
cinema operators would offer weekly changing programmes. Also, year-round film screenings are held in theatres, cinemas, schools or coffeehouses. Sami Dündar reports that for years, 300-400 people watched films at Cinema Arl in Arslanköy in a given screening. All of these show us that cinema is not only a city-specific phenomenon but even in the most remote villages the experience is intense. Therefore, the correlation between city (and being urban), cinema (and spectatorship) and modernity is not a necessary one; such relationships can be established for the villages as well.

\section{Conclusion: Taking a fresh look at the cinemagoers}

When the public is ready to feel before understanding, what a number of films reveal and explain everything to it!97

Our study on cinemagoing experiences in Taurus highland villages in the period from 1960 to 1980 challenges the dominant literature on Turkish cinema history based on the assumptions of the traditional/conventional modern approaches of metropolitan areas and city centres to the relationship between cinema and the city and modernity. The conventional approach that ignores cinemagoing in small towns and rural areas, lies far from explaining these activities and experiences. This distance allows us to problematise the notion of 'urban' audience within the context of cinemagoing experiences. First of all, in the Taurus highland villages, ontologically, cinema does not have to coexist with the formation of the city itself, as suggested in 'Gothamcentric' ${ }^{8}$ historiography. There are various locations where diversified cinemagoing experiences have been realised. Again, accordingly, the relationship between city, cinema, and modernity does not have to be a symbiotic relationship based on a triple condition. Modernity, like cinema, is a phenomenon experienced outside the cities in different geographies. As Berman aptly asserts:

To be modern is to experience personal and social life as a maelstrom, to find one's world and oneself in perpetual disintegration and renewal, trouble and anguish, ambiguity and contradiction: to be part of a universe in which all that is solid melts into air. To be a modernist is to make oneself somehow at home in the maelstrom, to make its rhythms one's own, to move within its currents in search of the forms of reality, of beauty, of freedom, of justice, that its fervid and perilous flow allows. ${ }^{99}$ 
Of course, we cannot claim that the inhabitants of the Taurus highland villages are in search of a total form of reality, beauty, freedom and justice. However, during our study, we witnessed all these emotions have been experienced more or less through cinema. Consequently, we need new perspectives on the relationship between city, cinema, and modernity.

However, we also need to review the preconceptions and prejudices of the traditional/ conventional approach to cinemagoing and exhibiting experiences. In addition to films, screenings have been performed in places of which examples can rarely be seen in the cities such as terrace/ rooftop cinemas, gardens, temporary screening places set up in the highlands, village squares, coffee houses, tea gardens and schools. Most of the time, these screening are not fixed but constantly changing places and venues have been used. Moreover, those who perform screenings are also travelling in many villages and highlands in the region. The cinema business has been carried out on a travelling basis. The cinema experience in the Taurus highland villages, unlike the proposition of the conventional approach, encompasses mobility in almost every aspect: First of all, the film -motion picture- ontologically refers to an action. The exhibitor who performs the screening is also mobile: instead of settling in a certain place, he performs screenings through following a certain route translocally. In this respect, the travelling exhibitor forms a network connecting certain villages. Finally, the audience is also travelling; they come from nearby villages, neighbourhoods or plains to the village where the screening will be held. Moreover, in contrast to the examples that we come across in metropolitan cinemas, the uniform viewing experience in silence has been replaced by a noisy and performative viewing experience. The audience is extremely 'undisciplined' but at the same time very active before the screen. In the end, cinema has reorganised the 'rural area' (often accused of being very static), as a very dynamic space. We need new perspectives and new approaches to analyse cinema history and cinemagoing experiences as the New Cinema History paradigm suggests. Biltereyst and colleagues' chapter ${ }^{100}$ focusing on a case study of cinema culture in the harbour cities of Antwerp and Rotterdam offers a wide literature on comparative works of historicising cinemagoing experiences and argues that expansions will only be possible through strengthening comparative research within new cinema history. We need fieldwork experiences that will transform our perspective and approach and develop new sets of concepts that will enable us to observe, analyse, interpret and transfer our experiences. The table below summarises such an attempt. 
Traditional / Conventional Approach

The relationship between cinema, city and modernity

Uniform venues and screening practices

Fixed-location, settled cinema venues and screening

Closure and cinema halls isolated from physical reality

Uniform audience and disciplined screening
New Approach

Cinema experience independent of urban settings

Movie theatres, terrace/rooftop cinemas, garden cinemas, highland cinemas, village squares, coffeehouses, tea gardens, schools etc.

Translocal, mobile and travelling cinema

Cinema spaces intertwined with openness and physical reality

Active and performative audience; various cinemagoing practices

Table 2. A New Approach to Modernity, City, Cinema and Audience Relations

Srinivas, who researches cinemagoing experiences taking place in the Indian context by employing ethnographic methodologies, says that film studies in her country were conducted under the leadership of educated middle-class researchers who were alienated from popular cinema. Therefore 'the indigenous dialogue between audience and cinema has [...] gone unnoticed.'101 The distance between researchers' subjective interest in the art of cinema and widely experienced cinemagoing practices and the audience makes the relation and relevance between two groups almost impossible. This provision made by Srinivas also explains some significant problems of film/ cinema studies in Turkey. These problems include firstly the fact that cinema studies in Turkey mostly focus on films and/or the directors and genres; secondly, the fact that İstanbul is located at the very centre of national cinema history; thirdly, that most of the studies about our history of cinema are detached from originality and repeated and conducted through secondary sources instead of primary sources. In addition, the assumption situated in most of the scholarship is that the audience also belongs to an upper-middle-class and are the residents of cities just like the researcher. This is combined with the adoption of conventional modern propositions as the only approach to explaining almost any issues related to cinema, and has led to the formation of a 
school of research and a group of researchers being alienated and far from explaining social and cultural experiences formed around cinemagoing. Today, however, the New Cinema History approach allows us to see that the audience and the cinemagoing experience are among the basic components of cinema studies as well as films or directors. Likewise, the necessity to go outside of İstanbul and initiate cinema studies in different localities is crucial in contemporary research. As we have witnessed, even from the first days of the research we conducted in the Taurus highland villages, we need new perspectives to be able to relate to and question the established understanding of cinema history. We need to ask new questions, put forward new definitions, and develop new methods for our research. As in the epigraph, Bresson states that it is important for any audience to try to feel any film before attempting to understand it. When the audience is ready to feel, the film will show and explain everything. We propose to re-frame Bresson's proposition within the new cinema studies paradigm: When the researcher is ready, the audience will have much to offer.

\section{Notes}

1 This article is based on two research projects funded by Çukurova University Seed Funding - BAP, Project No. SBA-2018-10631 (Travelling Cinema Experience in Taurus Mountains) and Project No. SBA-201911993 (Cinema Activities of Adana People’s House between 1933 to 1951).

2 Hakan Aydın, “Sinemanın Taşrada Gelişim Süreci: Konya’da İlk Sinemalar ve Gösterilen Filmler (1910-1950),” Selçuk Üniversitesi Sosyal Bilimler Enstitüsü Dergisi, 19 (2008): 61-74; Tunç Boran, “Erken Cumhuriyet Döneminde Taşrada Sinema Seyri: Çankırı Örneği,” İletişim Kuram ve Araştırma Dergisi, 41 (2015): 257-276; Ayşen Esra Bölükbaşı Ertürk \& Büşra Arslan, Safranbolu’da Sinemanın Gelişim Süreci: Özer Sinemas1,” History Studies, 11, no. 5 (2019): 1539-1; Esma Gökmen, “Samsun’da Sinema Mekanları Üzerine Bir Sözlü Tarih Çalışması,” Selçuk Üniversitesi İletişim Fakültesi Akademik Dergisi, 12, no. 1: 325-350; Arzu Ertaylan, “Yeşilçam Döneminde Van'ın Sinema Kültürü,” Turkish Studies: International Periodical for The Languages, Literature and History of Turkish or Turkic, 8, no. 8 (2013): 1839-1857.

3 Daniel Biltereyst and Philippe Meers, "New Cinema History and the Comparative Mode: Reflections on Comparing Historical Cinema Cultures”, Alphaville 11 (2016): 13-32, 21.

4 Nijat Özön, Türk Sineması Kronolojisi (1895-1966), (İstanbul: Bilgi Yayınevi, 1968). 
5 Robert C. Allen, “Decentering Historical Audience Studies," in Hollywood in the Neighborhood: Historical Case Studies of Local Moviegoing, ed. Kathryn Fuller-Seeley, (Berkeley, LA: University of California Press, 2008), 20-33, 20.

6 Kurtuluş Kayalı, “Türk Sinema Tarihlerinin Sınırlarını Aşmanın Yolları,” in Türk Sineması Üzerine Düşünceler, ed. Süleymâ Murat Dinçer, 57-74, (Ankara: Doruk Yayınları., 1996); Murat Akser, “Türk Sinema Tarihi Yazılımı: Bir Yöntem Önerisi,” in Türk Film Araştırmalarında Yeni Yönelimler 3 - Karşılaşmalar, ed. Esra Özcan, 41-48, (İstanbul: Bağlam Yayınları, 2003); Altuğ Işığan, "Sinema Tarihi Yazarlığı İçin Alternatif Arayışları: Yenileme mi, Yineleme mi?”, Türk Film Araştırmalarında Yeni Yönelimler 4 - Türk Sineması: Hayalî Vatanımız, ed. Esra Özcan, 121-128, (İstanbul: Bağlam Yayınları, 2004); Övgü Gökçe, “Türk Sinemasının Sözlü Tarihini Ararken: İlhan Arakon,” Türk Film Araştırmalarında Yeni Yönelimler 5 - Sinema ve Tarih, ed. Elif Akçalı, 81-92, (İstanbul: Bağlam Yayınları, 2006); Emrah Özen, “Geçmişe Bakmak: Sinema Tarihi Çalışmaları Üzerine Eleştirel Bir İnceleme,” Kebikeç, 27 (2009a): 131-155; Emrah Özen, “Özön’ün Paltosundan Kurtulmak: Türkiye Sineması Tarihi Çalışmalarının Eleştirel Bir Değerlendirilmesi,” İletişim: Araştırmaları, 7, no. 1-2 (2009b): 13-47; Emrah Özen, “Sinema Tarihi Çalışmalarında Önemli Bir Proje: HOMER,” sinecine, 4, no. 2 (2013): 155-165, Mehmet Özen, “Hareketli Resimler”; Nezih Erdoğan, Sinemanın İstanbul'da İlk Yılları: Modernlik ve Seyir Maceraları (İstanbul: İletişim Yayınları, 2017).

7 Esra Biryıldız, “Kent Dışında Sinema,” in Kentte Sinema Sinemada Kent, ed. Nurçay Türkoğlu, Mehmet Öztürk \& Göksel Aymaz, 53-55, (İstanbul: Yeni Hayat Yayıncılık, 2004), 55.

8 Retrieved from http://www.tuik.gov.tr, accessed on 25 August 2019.

9 Eric J. Hobsbawm, Age of Extremes - The Short Twentieth Century 1914-1991, (London: Abacus, 1995), 291.

10 Savaş Arslan, Cinema in Turkey: A New Critical History, (New York: Oxford University Press, 2011), 100.

11 Turgut Çeviker, “Genelev Kadınlarıyla Sinema Soruşturması,” Yedinci Sanat, 18 (1974): 35-41; Turgut Çeviker, “Bir Anadolu Kasabasında Sinema Soruşturması,” Yedinci Sanat, 24 (1975): 40-49.

12 Hilâl Atan, “Kocaeli Yöresi Türk ve Çin Filmleri Sorușturması,” Yedinci Sanat, 20 (1975): 64-69.

13 Zeki Yusuf Borazan, “Arkadaș Üzerine Halk Soruşturması,” Yedinci Sanat, 21 (1975): 26-29.

14 Osman Şahin, “Toros Dağları'nda Sinema Soruşturması,” Yedinci Sanat,19 (1974): 50-53.

15 Mazhar Necati, “1924’te İzmir’de Sinema Hayatı,” Toplumsal Tarih Dergisi, 6 (1994): 51-52. 
16 Mesut Çapa, “Milli Mücadele'den Cumhuriyet’e Trabzon'da Tiyatro ve Sinema,” Toplumsal Tarih Dergisi, 94 (2001): 22-28.

17 Süleyman Beyoğlu, “Sinema Karadeniz’de (1909-1933),” Toplumsal Tarih Dergisi, 92 (2001): 47-50.

18 Gülseren Mungan Yavuztürk, “Ankara’da Bir ‘Büyük Sinema’ Vardı,” Kebikeç, 28 (2009): 163-168.

19 Güzin Emecan, “Bulancak’ta Sinema Şemsi Emecan’la Konuşma,” Kebikeç, 28 (2009): 169-176.

20 Cantürk Coşkun, “Mustafa Usta’nın ‘Kader Sineması’ (Oltu 1961-1977),” Kebikeç, 28 (2009): 177-185.

21 Dilek Kaya, "Remembering The First Movie Theaters and Early Cinema Exhibition in Quay, Smyrna, Turkey,” in The Routledge Companion to New Cinema History, eds. Biltereyst, Daniël, Richard Maltby \& Philippe Philippe, 244-253, (New York: Routledge, 2019); Oğuz Makal, Tarihin Penceresinden İzmir Sinemaları (1909-1930), (İzmir: Alo Bilgi Kültür Yayını, 2002).

22 Dilek Kaya, “Eski İzmir Sinemaları ve Yıldız Sineması: Mekân, Toplum, Seyir,” sinecine, 8, no. 2 (2017): 93-138.

23 Hakan Aydın, “Sinemanın Taşrada Gelişim Süreci: Konya’da İlk Sinemalar ve Gösterilen Filmler (1910-1950).”

24 Arzu Ertaylan, “Yeşilçam Döneminde Van’ın Sinema Kültürü,”

25 Ali Sait, “Liman, Gaziantep’te Sinema, Seyir ve Seyirci (1923-1980),” İstanbul Üniversitesi İletişim Fakültesi Dergisi, 47 (2014): 97-123.

26 Meltem Özkan Altınöz, “Endüstri Kenti Karabük’ün Sosyal Yaşantısının Şekillenişinde Yenişehir Sineması'nın Rolü,” Itobiad: Journal of The Human \& Social Science Researches, 4, no. 1 (2015): 83-99. İnal Karagözoğlu, Ankara’da Sinemalar Vardı... (İstanbul: Bilişim Yayınevi, 2004); Burçak Evren \& Ali Karadoğan, Sinemada Son Adam: Makinist Ramazan Çetin - Ankara Sinemaları Tarihi, (Ankara: DKIV Yayınları, 2008); Gülseren Mungan Yavuztürk, “Ankara’da Yayımlanmış Sinema Dergilerinin Kısa Tarihçesi," Ankara Araştırmaları Dergisi, 1, no. 2 (2013): 79-92. Hasan Akbulut, et al, Kültürel ve Toplumsal Bir Pratik Olarak Sinemaya Gitmek: Türkiye’de Seyirci Deneyimleri Üzerine Bir Sözlü Tarih Çalışması Projesi Sonuç Raporu (Proje No: 115K269), (Ankara: TÜBİTAK, 2018a).

29 Hasan Akbulut, “Cinemagoing as a Heterogeneous and Multidimensional Strategy: Narratives of Woman Spectators," The Turkish Online Journal of Design Art and Communication, 7, no. 4 (2017): 530-541; Hasan Akbulut, “Bir Seyirci Araştırmasından Etnografik Deneyimler ve Hikâyeler,” Folklor/Edebiyat, 95, no. 24 (2018b): 13-34; Emine Uçar İlbuğa, “1960-1970’li Yıllarda Kent ve Taşra Karşıtllğında Türkiye’de 
Kadınların Sinema İzleme Pratikleri Üzerine Bir Araştırma,” İletişim Kuram ve Araştırma Dergisi, 45 (2017): 388-402; Emine Uçar İlbuğa, “1960-1970’li Yıllarda Antalya’da Sinema İzleme Deneyimi,” İlef Dergisi, 5, no. 1 (2018): 61-90.

30 Daniel Biltereyst and Philippe Meers, “New Cinema History and the Comparative Mode”, 18.

31 see Richard Maltby, Daniel Biltereyst and Philippe Meers (eds.), Explorations in New Cinema History: Approaches and Case Studies, (Oxford: Blackwell, 2011); Biltereyst and Meers, "New Cinema History and the Comparative Mode"; Daniel Biltereyst, Thunnis van Oort and Philippe Meers, “Comparing historical cinema cultures: Reflections on new cinema history and comparison with a cross-national case study on Antwerp and Rotterdam," in Routledge companion to new cinema history, eds. Daniel Biltereyst, Richard Maltby, and Philippe Meers, 96-111, (London; New York, NY: Routledge, 2019).

32 Annette Kuhn, “A journey through memory”, in Memory and Methodology, ed. Susannah Radstone, 179-196, (New York, NY: Berg, 2000); Annette Kuhn, "Heterotopia, heterochronia: place and time in cinema memory”, Screen 45, no. 2 (2004): 106-114; Daniela Treveri Gennari, “Understanding the Cinemagoing Experience in Cultural Life: The Role of Oral History and the Formation of 'Memories of Pleasure’," Journal for Media History, 21, no. 1 (2018): 39-53.

33 Kevin Brownlow, The Parade’s Gone By... (Londra: Secker \& Warburg, 1968).

34 Stephen Caunce, Oral History and Local Historian, (London: Longman, 1994).

35 Maltby, Biltereyst and Meers, Explorations in New Cinema History.

36 Richard Maltby, Melvyn Stokes, and Robert Clyde Allen (eds.), Going to the Movies: Hollywood and the Social Experience of Cinema, (Exeter: University of Exeter Press, 2007).

37 Daniela Treveri Gennari, Danielle Hipkins, and Catherine O’Rawe (eds.), Rural Cinema Exhibition and Audiences in a Global Context, (Cham: Palgrave Macmillan, 2018).

38 Åsa Jernudd, "Spaces of early film exhibition in Sweden, 1897-1911", in Cinema, Audiences and Modernity: New Perspectives on European Cinema History, eds. Daniel Biltereyst, Richard Maltby, Philippe Meers, 19-34, (London: Routledge, 2013).

39 Karina Aveyard, Lure of the Big Screen: Cinema in Rural Australia and the United Kingdom, (Bristol, UK: Intellect, 2015).

40 Katherine Bowles, "The Last Bemboka Picture Show: $16 \mathrm{~mm}$ Cinema as Rural Community Fundraiser in the 1950s," in Explorations in New Cinema History: Approaches and Case Studies, eds. Maltby, Biltereyst, and Meers, 310-321, (Oxford: Blackwell, 2011). 
41 Philippe Meers, Daniel Biltereyst, and Lies Van De Vijver, “Metropolitan vs Rural Cinemagoing in Flanders, 1925-75,” Screen 51, no. 3 (2010): 272-280.

42 Corinne Marache, "Cinema and social Life in the Rural Gironde: Insights from an Oral History Project" in Cinema Beyond the City: Small-Town and Rural Film Culture in Europe, ed. J. Thissen and C. Zimmermann, (London: British Film Institute, 2016), 105-129.

43 Yvonne Zimmermann, "Corporate Film Shows and the Initiation of Rural Audiences to Film and Consumer Culture in Switzerland" in Cinema Beyond the City: Small-Town and Rural Film Culture in Europe, ed. J. Thissen and C. Zimmermann, (London: British Film Institute, 2016), 133-148.

44 Daniel Biltereyst and Lies Van de Vijer, "Cinema in the 'Fog City': Film Exhibition and Sociogeography in Flanders" in Cinema Beyond the City: Small-Town and Rural Film Culture in Europe, ed. J. Thissen and C. Zimmermann, (London: British Film Institute, 2016), 223-236.

45 Judith Thissen, "Film Consumers in the Country: The Culture and Business of Small-Town and Rural Cinemagoing in the Netherlands" in Cinema Beyond the City: Small-Town and Rural Film Culture in Europe, ed. J. Thissen and C. Zimmermann, (London: British Film Institute, 2016), 87-104.

46 Gunter Mahlerwein, "Alternative Cinema in the Youth Centre Movement in Germany in the 1970s and 1980s" in the Netherlands" in Cinema Beyond the City: Small-Town and Rural Film Culture in Europe, ed. J. Thissen and C. Zimmermann, (London: British Film Institute, 2016), 181-193.

47 Thunnis van Oort, “'Coming up This Weekend': Ambulant film Exhibition in the Netherlands” in Cinema Beyond the City: Small-Town and Rural Film Culture in Europe, ed. J. Thissen and C. Zimmermann, (London: British Film Institute, 2016), 149-164.

48 Lakshmi Srinivas, House full: Indian Cinema and the Active Audience, (Chicago: University of Chicago Press, 2016).

49 We would like to thank to young researchers Elif Şimşek, Eren İlbuğa, Hande Canbolat, Necati Öz and Yıldırım Yeniçeri for their interest in learning local cinema history and for their assistance during the fieldwork.

50 Suavi Aydın, “Toroslarda Yaylacılık ve Çukurova’nın Önemi,” Kebikeç, 21 (2006): 111-134.

51 İlke Şanlıer Yüksel and Aydın Çam “Çukurova’da 1960-1980 Dönemi Sinema Pratiklerinin Özel Bir Örneği: Yörük Filmleri”, sinecine: Sinema Araștırmaları Dergisi 10, no. 2 (2019): 291-320. 
52 Mehmet Pınar, Cumhuriyet Döneminde Mersin ve İçel'de Siyasi Hayat (1923-1959), (Ankara: HiperYayın, 2018); Erdem Çanak, “Akgünler Gazetesi ve Gazetede Adana Halkevi,” Atatürk Araştırma Merkezi Dergisi, 29, no. 85 (2013): 1-45.

53 Özgür Adadağ, “From 'people’s education' to people's entertainment: the changing role of cinema in Turkey’s People’s Houses (1932-1950),” Middle Eastern Studies 56, no. 3 (2020): 453-468.

54 Ibidem, 454.

55 Åsa Jernudd and Mats Lundmark, "Cinemagoing in Sweden in the 1940s: Civil Society Organisations and the Expansion of Rural Film Exhibition”, in Cinema Beyond the City: Small-Town and Rural Film Culture in Europe, ed. J. Thissen and C. Zimmermann, (London: British Film Institute, 2016), 67-86.

56 Eyal Ari, “The People’s Houses and the Theatre in Turkey,” Middle Eastern Studies, 40, no. 4 (2004): 32-58.

57 Osman Şahin, “Toroslar’da Sinema Çerçileri,” in Türk Sineması Üzerine Düşünceler, ed. S. M. Dinçer, (Ankara: Doruk Yayınları, 1996), 301-307.

58 Although it is not mentioned in the article of Şahin which Tarzan movie is shown, as can be guessed from the date, it is probably the one that was directed W.S. Van Dyke and released in 1932.

59 Osman Şahin, “Toroslar’da Sinema Çerçileri,” 304.

60 Ibidem, 305.

61 Amerikan Haberler Merkezi (USIS), Türkiye Film Kataloğu (16 mm ve 35 mm), (Ankara: Doğuş Matbaası, 1952), 6.

62 Ibidem.

63 Ibidem, 16.

64 David Harvey, The Condition of Postmodernity - An Enquiry into the Origins of Cultural Change, (Cambridge \& Oxford: Blackwell Publishers, 1990), 207. Interview conducted on 30 August 2018.

66 Interview conducted on 30 August 2018.

67 Interview conducted with Saim Dinçer on 28 August 2018.

68 Thunnis van Oort, "Coming up This Weekend".

69 For a more detailed discussion, see İlke Şanlıer Yüksel and Aydın Çam “Çukurova'da 1960-1980 Dönemi Sinema Pratiklerinin Özel Bir Örneği: Yörük Filmleri”.

70 Osman Şahin, “Toros Dağları'nda Sinema Soruşturması”.

71 Ibidem, 51. 


\section{no. 4 (1998): 323-353; Lakshmi Srinivas, “The active audience: spectatorship,
experience of cinema in India”, Media, Culture \& Society, 24 (2002): 155-173.}

75 Interview conducted with F. Ay on 13 July 2018.

76 Interview conducted with E. Yıldız on 13 July 2018 and interview conducted with S. Öz on 28 August 2018.

77 Thomas Elsaesser, and Malte Hagener, Film Theory: An Introduction through the Senses, (New York, NY: Routledge, 2010), 18-19.

Interview conducted on 30 August 2018. Çağlar, Halkevleri 1932-1935: 103 Halkevi Geçen Yıllarda Nasıl Çalıştı?, (Ankara: Ulus Basımevi, 1935). Interview conducted with M. Kizir on 13 July 2018. Interview conducted with S. Öz on 28 August 2018. Interview conducted with S. Dündar on 26 July 2018. Interview conducted with B. Ay and F. Ay on13 July 2018. Interview conducted on 30 August 2018. Interview conducted with H. Kınalı on 30 August 2018; interview conducted with Sabri Şenevi on 13 December 2018.

Interview conducted with S. Dündar on 26 July 2018. Interview conducted with F. Ay on 13 July 2018. Lakshmi Srinivas, "Active viewing”; Lakshmi Srinivas, "The active audience”. Mario Pezzella, Estetica del cinema, (Bologna: Il Mulino. 2010). Jean-Paul Sartre, “Motion Picture Art," in The Writings of Jean-Paul Sartre - Volume 2, Selected Prose, eds. Michel Rybalka and Michel Contat, 53-59, (Evanston: Northwestern University Press, 1974), 59.

9 Eric J. Hobsbawm, Age of Empire, 1875-1914, (New York: Vintage, 1989), 238.

John Orr, Cinema and Modernity, (Cambridge: Polity Press, 1993), 17.

91 In this respect, the results of the field study we conducted at Taurus highland villages and the results of some studies carried out in Flemish villages (e.g. Meers, Biltereyst \& Van De Vijver, "Metropolitan vs Rural Cinemagoing in Flanders") correspond. For both geographies, regardless of class or the frequency of experience, cinema is as important to villagers as it is to urbanites, and moreover, the cinema experience in 
the villages - as explained above - has a demolishing effect on stereotypical view of the relationship between city and modernity.

92 Biltereyst, Maltby and Meers, Explorations in New Cinema History.

93 Interview conducted on 13 July 2018.

94 Interview conducted on 26 July 2018.

95 Interview conducted with S. Dündar, 26 July 2018.

96 Interview conducted with S. Öz on 28 August 2018.

97 Robert Bresson, Notes on Cinematography, (New York: Urizen Books, 1977), 59.

98 Robert C. Allen, “Decentering Historical Audience Studies.”

99 Marshall Berman, All That is Solid Melts into Air - The Experience of Modernity, (New York: Penguin Books, 1988), $345-346$.

100 Biltereyst, van Oort and Meers, “Comparing Historical Cinema Cultures”.

101 Srinivas, “The Active Audience”, 156.

\section{Biographies}

Aydın Çam is an assistant professor in the School of Communications at Çukurova University. He got his BA degree from Department of Communication Sciences at Marmara University and a PhD degree from Media and Communication Studies Program at Galatasaray University. His research mainly focuses on the New Cinema History, cinema history of Çukurova, cinemagoing, and spectatorship. Currently, he works on travelling cinema experiences in Taurus' highland villages, nomad (Yörük) films, and mapping of Adana cinema history. He is also interested in cinema and space relations such as cinematic spaces, spatial experiences, and mapping the cinematic spaces.

İlke Şanlıer Yüiksel is an assistant professor in the School of Communications at Çukurova University, and serves as the director of Migration and Development Studies Research Center (MIGCU). She received her BA degree from Sociology Department at Boğaziçi University and a PhD degree from Communication program at Anadolu University. Her research mainly focuses on the sociology of migration and the sociology of cinema. She works on media's role in diasporic cultures, transnational politics through mediated settings, cinema and mobility. She has a long experience of field research and ethnographic research on migrants and cinema history in Adana. 


\section{TMG Journal for Media History}

Volume 23 No (1/2)/2020

\section{DOI}

https://doi.org/10.18146/tmg.600

\section{PUBLISHER}

Netherlands Institute for Sound and Vision

\section{COPYRIGHT}

Each article is copyrighted (c) by its author(s) and is published under license from the author(s). When a paper is accepted for publication, authors will be requested to agree with the Creative Commons Attribution 4.0 International License. 